\title{
Quality by Design Approach for Design, Development and Optimization of Orally Disintegrating Tablets of Montelukast Sodium
}

\author{
Hasan Pasha Nazeer Ahmed Sholapur ${ }^{1}$, Fatima Sanjeri Dasankoppa ${ }^{2,}$, Mudlapur Channabasavaraja ${ }^{2}$, Revati Dharampal Sagare ${ }^{2}$, Zaheer \\ Abbas $^{3}$, Nanjangud Gangadhariah Nanjunda Swamy ${ }^{4}$, Lakshmi Swapna Sai ${ }^{2}$, Kamaladevi Kshatriya ${ }^{5}$ \\ 'Department of Pharmacognosy, KLE College of Pharmacy, Vidyanagar, Hubballi, Karnataka, INDIA. \\ ${ }^{2}$ Department of Pharmaceutics, KLE College of Pharmacy, Vidyanagar, Hubballi, Karnataka, INDIA. \\ ${ }^{3}$ Senior Research Scientist, Apotex Pvt. Ltd. Bangalore, Karnataka, INDIA. \\ ${ }^{4}$ Department of Pharmaceutics, Government College of Pharmacy, Bangalore, Karnataka, INDIA. \\ ${ }^{5}$ Department of Pharmaceutics, KLE College of Pharmacy, Vidyanagar, Hubballi, Karnataka, INDIA.
}

\begin{abstract}
Background: The goal of this research was to use the Quality by Design $(\mathrm{QbD})$ approach to develop orally disintegrating tablets of Montelukast sodium, a leukotriene receptor antagonist used to treat asthma. Characterizing the reference product, defining the quality target product profile (QTPP), identifying critical quality attributes (CQAs), and performing initial testing are all parts of the $\mathrm{ObD}$ approach and relating the critical material attributes (CMAs) and critical process parameter (CPP) to drug product CQAs, as a result to develop the design space and defining control strategy. Method: Montelukast sodium tablets were designed using direct compression technique. Formulation were designed by using (DOE software $\checkmark$ 13.2) $2^{3}$ full factorial design in which three variables namely croscarmellose sodium (CCS), microcrystalline cellulose (MCC) and magnesium stearate were varied at two levels by considering one center point. Results: The disintegration time and in vitro dissolution were considered as responses and the prepared tablets have been evaluated for various quality
\end{abstract}

control tests. Formulation F5 was considered as optimized as it showed minimum disintegration time and maximum drug release profile. Conclusion: The CMAs classified as high or medium risk in the initial risk assessment were mitigated to low risk based on the experimentation. Finally, a control strategy was defined giving better control over drug product development. Key words: Orally disintegrating tablets, Montelukast sodium, Quality by Design (QbD), Design of Experiment, Direct Compression, Control strategy.

Correspondence

Dr. Fatima S Dasankoppa, Professor, Department of Pharmaceutics, KLE College of Pharmacy, Vidyanagar-560010, Hubballi, Karnataka, INDIA.

Email id: fsdasankop@gmail.com

DOI: 10.5530/ijpi.2021.3.51

\section{INTRODUCTION}

Oral route of administration is regarded as the better route, as a result of ease of ingestion, avoiding pain, easy manufacturing and considerable patient acceptability. ${ }^{1}$ The major drawback of solid unit dosage forms like capsules and tablets is painful while swallowing (i.e., dysphagia) which leads to patient unacceptability mainly in paediatric as well as geriatric patients. USFDA defined Oral Disintegrating Tablet (ODT) as "A solid dosage form containing medicinal substance or active ingredient which disintegrates rapidly usually within a matter of seconds when placed upon the tongue". ${ }^{2}$ These dosage forms are also known as fast disintegrating tablets, oro-dispersible tablets, mouth dissolving tablets, fast dissolving tablets and rapid dissolving tablets. These terminologies were approved by United States Pharmacopoeia (USP) as ODTs. Since the expense of producing a new medication entity is relatively high, pharmaceutical firms are focusing their efforts on developing innovative dosage models for previously available medications that combine protection and effectiveness while reducing dosing frequency and allowing for cost-effective manufacture of these dosage units.

Montelukast sodium is a selective antagonist of the leukotriene receptor that inhibits the cysteinyl leukotriene receptor and is used as an alternative to anti-inflammatory drugs in the prevention and treatment of asthma, exercise-induced bronchospasm, and seasonal allergy symptoms. It is commonly administered orally. Montelukast sodium is a powder that is white to off-white in color. It is soluble in ethanol, methanol, and water, but almost insoluble in acetonitrile. Montelukast has a 64 percent of oral bioavailability and more than 99 percent bound to plasma proteins with minimal distribution across the blood-brain barrier. Metabolism occurs via liver and excretion occurs almost exclusively in bile with a half-life from 2.7 to $5.5 \mathrm{~h}$ in healthy adults. Montelukast is substantially metabolized by cytochrome P450 3A4 and 2C9 in the liver. Montelukast sodium is available in a variety of dosage forms, including a $10 \mathrm{mg}$ film-coated tablet and 4 to $5 \mathrm{mg}$ chewable tablets. ${ }^{3}$

QbD approach is a paramount shift from traditional approach where in quality of the products was ensured by final testing of the products. International Council for Harmonization (ICH) describes the principles of $\mathrm{QbD}$ and also addresses the major targets with respect to quality issues. ICH Q8 defines the aspects related to quality by design, whereas ICH Q9 describes the pharmaceutical risk management, and finally ICH Q10 gives an idea about pharmaceutical quality system.

Quality by Design is defined as "A systematic approach to development that begins with predefined objectives and emphasizes product and process understanding and process control, based on sound science and quality risk management".

Quality by Design development process includes:

This is an open access article distributed under the terms of the Creative Commons Attribution-NonCommercial-ShareAlike 4.0 License, which allows others to remix, tweak, and build upon the work non-commercially, as long as the author is credited and the new creations are licensed under the identical terms. 
1. Defining Quality Target Product Profile (QTTP) which links to quality, efficacy as well as safety for example: dosage form, strength, route of administration, stability and bioavailability.

2. Once the Critical Quality Attributes (CQAs) of a drug product has been determined, the features of the product will have an impact on the quality of product that can be analyzed and regulated.

3. Choosing a suitable manufacturing procedures.

4. Define a control strategy. ${ }^{4}$

The present work aims to design and flourish oral disintegrating tablets of Montelukast Sodium using the concept of Quality by Design (QbD) by means of quality risk management. Formulations were optimized by using Design of Experiments (DoE) to minimize the risk level and also to reduce the risk assessment. Risk assessment was performed before inflicting DoE and again it was reevaluated after inflicting DoE. This leads to minimize the risks involved in the fabrication of ODTs and present a good quality product.

\section{MATERIALS AND METHODS}

\section{Materials}

Montelukast sodium was procured as gift sample from Apotex Research Private Ltd (Bangalore, India), croscarmellose sodium was from Elegant Pharma (Hubballi, India) as a gift, microcrystalline cellulose and magnesium stearate were purchased from Elegant Pharma (Hubballi, India). All the other reagents and chemicals used were of analytical grade.

\section{Defining Quality target product profile (QTPP) of drug product}

Identification of QTPP is an important part of QbD approach as it forms the basis for drug product development. The QTPP is a list of the quality attributes of a drug product that will be achieved to certify the drug product's desired quality, effectiveness, and safety. Characterization of the reference listed drug product (Brand Name: Singulair) and all the parameters defining its quality were studied viz: appearance, content uniformity, assay, dissolution and disintegration time as shown in Table 1. Based on the reference listed drug product (RLD), QTPP's for Montelukast ODTs were set as target with justification as shown in Table 2 .

\section{Identification of Critical Quality Attributes (CQAs) of drug product}

Following the definition of the drug product's QTPP, the next step is to identify the quality attributes that are essential to the drug product's quality. The CQAs should be controlled to make sure that the product achieves desired efficacy, safety and stability. Initial risk assessment revealed by controlling CQAs which includes the parameters such as assay, content uniformity, dissolution and disintegrating time and the quality can be imbibed as RLD as shown in Table 3.

\section{Initial risk assessment of formulation variables for Montelukast sodium orally disintegrating tablets}

The aim of doing an initial risk evaluation of formulation variables is to see how CMAs affect the drug product's CQA. The initial risk assessment along with justification was shown in Table 4. Risk assessment was meticulously carried and CQAs were designated as high, low and medium risk to assess the prominent parameters effecting CQAs. ${ }^{5}$

\section{Formula optimization}

Formula optimization was carried out by focusing on the high as well as medium risk formulation variables as recognized in the initial risk assessment. The concentration of disintegrant, diluent and lubricant i.e.
Table 1: Characterization of reference product.

\begin{tabular}{ccc}
\hline S No & Parameters & Characterization \\
\hline 1 & Name & Chewable Montelukast sodium \\
2 & API & Montelukast sodium \\
3 & Dosage form & Chewable tablet \\
4 & Strength (mg) & 5 \\
5 & Description & $\begin{array}{c}\text { Pink round tablet embossed with } \\
\text { code MSD 275 on one side and } \\
\text { singular on other side }\end{array}$ \\
6 & Diameter (mm) & $9.6 \pm 0.003$ \\
7 & Thickness (mm) & $4.8 \pm 0.020$ \\
8 & Average weight (mg) & $304.3 \pm 0.69$ \\
9 & Hardness (kg/cm $\left.{ }^{2}\right)$ & $9.5 \pm 0.44$ \\
10 & Disintegration time (s) & 25 \\
11 & Dissolution at 30 min & 98.15 \\
12 & (\%CDR) & 98.35 \\
13 & Drsay (\%) & 98.97 \\
\hline
\end{tabular}

CDR indicates Cumulative Drug Release

\begin{tabular}{|c|c|c|c|}
\hline S. No & QTPP elements & Target & Justification \\
\hline 1 & Dosage form & Tablet & $\begin{array}{l}\text { Pharmaceutical } \\
\text { Equivalence }\end{array}$ \\
\hline 2 & Dosage design & $\begin{array}{c}\text { Rapidly } \\
\text { disintegrating }\end{array}$ & $\begin{array}{c}\text { For better therapeutic } \\
\text { efficiency }\end{array}$ \\
\hline 3 & Route of administration & Oral & $\begin{array}{l}\text { Pharmaceutical } \\
\text { equivalence }\end{array}$ \\
\hline 4 & Dosage Strength & $5 \mathrm{mg}$ & $\begin{array}{c}\text { Pharmaceutical } \\
\text { equivalence }\end{array}$ \\
\hline 5 & $\begin{array}{c}\text { Drug product quality } \\
\text { attributes- Appearance, } \\
\text { Friability, Assay, } \\
\text { Dissolution, Content } \\
\text { uniformity, Hardness, } \\
\text { Disintegration time }\end{array}$ & - & $\begin{array}{l}\text { Pharmaceutical } \\
\text { equivalence } \\
\text { meeting the same } \\
\text { compendial standards }\end{array}$ \\
\hline
\end{tabular}

croscarmellose sodium, microcrystalline cellulose and magnesium stearate were optimized respectively by using DOE software v 13.2. Table 5.

\section{Risk assessment of formulation variables has been updated.}

Acceptable ranges of formulation variables have been determined and integrated into the control strategy as high and medium risks. The initial risk evaluation of formulation variables was revised based on the results of formulation production studies.

\section{Defining control strategy}

Control strategy is a pre-determined collection of controls based on existing process and product knowledge that ensures product quality. This includes drug material, drug product part, process parameter, and finished product specification parameters. ${ }^{6}$ 
Table 3: Risk assessment for Critical quality attributes (CQAs) of Montelukast ODTs.

\begin{tabular}{|c|c|c|c|}
\hline Drug product attributes & Target & $\begin{array}{l}\text { Critical } \\
\text { Yes/No }\end{array}$ & Justification of criticality \\
\hline Appearance & Color and shape & No & Color and shape not associated to safety and efficacy. Not Critical \\
\hline Odour & Not pleasant odour & No & $\begin{array}{c}\text { Odor is not linked to safety and quality, but may affect patient acceptability. Hence, no } \\
\text { unpleasant odor excipients were used }\end{array}$ \\
\hline Size & Equivalent to RLD & No & Patient compliance \\
\hline Friability & Not more than $1.0 \%$ & No & Compendial requirement. Low impact on safety \\
\hline Assay & $98-102 \%$ as per IP & Yes & Variability in assay will affect safety and efficacy. CRITICAL \\
\hline Content uniformity & Conforms USP & Yes & $\begin{array}{l}\text { Content uniformity variability will influence safety and efficacy. Formulation Process variables } \\
\text { impact content Uniformity. CRITICAL }\end{array}$ \\
\hline Dissolution & $\begin{array}{l}\text { Not less than } 80 \% \text { in } \\
30 \mathrm{~min}\end{array}$ & Yes & $\begin{array}{l}\text { Not meeting the dissolution specifications can affect bioavailability } \\
\text { CRITICAL }\end{array}$ \\
\hline Hardness & $\begin{array}{l}\text { Not more than } \\
\text { 12kilopascal }\end{array}$ & Yes & $\begin{array}{l}\text { hardness delays disintegration time } \\
\text { CRITICAL }\end{array}$ \\
\hline Disintegration time & Less than $60 \mathrm{~s}$ & Yes & $\begin{array}{l}\text { Effects drug release which may affect efficiency } \\
\qquad \text { CRITICAL }\end{array}$ \\
\hline
\end{tabular}

Table 4: Initial risk assessment of formulation variables.

\begin{tabular}{|c|c|c|c|}
\hline $\begin{array}{c}\text { Formulation } \\
\text { Variables }\end{array}$ & $\begin{array}{l}\text { Drug Product } \\
\text { CQA }\end{array}$ & Risk & Justification \\
\hline \multirow[t]{2}{*}{$\begin{array}{l}\text { Microcrystalline } \\
\text { cellulose (MCC) }\end{array}$} & $\begin{array}{c}\text { Content } \\
\text { Uniformity }(\mathrm{CU})\end{array}$ & High & $\begin{array}{l}\text { MCC has impact on flow } \\
\text { properties which affects } \\
\text { the content uniformity }\end{array}$ \\
\hline & $\begin{array}{c}\text { Disintegration } \\
\text { time and } \\
\text { Dissolution }\end{array}$ & Medium & $\begin{array}{c}\text { Level of MCC affects } \\
\text { hardness which impacts } \\
\text { both the CQAs. }\end{array}$ \\
\hline \multirow[t]{3}{*}{$\begin{array}{l}\text { Croscarmellose } \\
\text { sodium(CCS) }\end{array}$} & $\begin{array}{c}\text { Content } \\
\text { uniformity }\end{array}$ & Low & $\begin{array}{c}\text { Since low levels of CCS } \\
\text { Sodium (CCS) are used, } \\
\text { it has low }\end{array}$ \\
\hline & & & impact on flow property. \\
\hline & $\begin{array}{l}\text { Disintegration } \\
\text { time Dissolution }\end{array}$ & High & $\begin{array}{c}\text { The levels of CCS affect } \\
\text { both the CQAs. }\end{array}$ \\
\hline \multirow[t]{3}{*}{$\begin{array}{l}\text { Magnesium } \\
\text { stearate }\end{array}$} & $\begin{array}{c}\text { Content } \\
\text { uniformity }\end{array}$ & Low & $\begin{array}{c}\text { Used in Less } \\
\text { concentration hence has } \\
\text { less impact on Content } \\
\text { uniformity. }\end{array}$ \\
\hline & $\begin{array}{l}\text { Disintegration } \\
\text { time }\end{array}$ & Low & $\begin{array}{c}\text { It enhances } \\
\text { Disintegration time. }\end{array}$ \\
\hline & Dissolution & High & $\begin{array}{c}\text { Excess lubrication affects } \\
\text { drug release. }\end{array}$ \\
\hline
\end{tabular}

\section{METHODS}

\section{Formulation design using $2^{3}$ full factorial design model}

Formulation was designed by using DOE software v 13.2 by considering 3 factors at 2 levels with 1 center point Table 6. Two responses, in vitro dissolution at $30 \mathrm{~min}$ and disintegration time were selected from the CQAs.

\section{Method of preparation of orally disintegrating tablets of} Montelukast sodium by direct compression method

The tablets were developed by direct compression technique using croscarmellose sodium (CCS) as super-disintegrate. The composition for each formulation of ODTs of Montelukast sodium was shown in Table 6.
Table 5: $2^{3}$ level factorial design for oral disintegrating tablets.

\begin{tabular}{ccc}
\hline $\begin{array}{c}\text { Independent Variables } \\
\text { (Factors) }\end{array}$ & Low & High \\
\cline { 2 - 3 } $\begin{array}{c}\text { Factor 1: } \\
\text { Croscarmellose sodium(CCS) } \\
\text { Factor 2: }\end{array}$ & $\mathbf{1}$ & $\mathbf{5}$ \\
$\begin{array}{c}\text { Microcrystalline cellulose (MCC) } \\
\text { Factor 3: }\end{array}$ & $\mathbf{2 5}$ & $\mathbf{7 5}$ \\
Magnesium stearate & $\mathbf{1}$ & $\mathbf{2}$ \\
\hline
\end{tabular}

All the excipients except lubricant (magnesium stearate) was passed through $60 \#$ mesh. The ingredients were then precisely weighed and combined in a geometrical order like (diluents, glidant, color, sweetener, taste and lubricant). The powder blend was lubricated with magnesium stearate and compressed into tablets by using single tablet punch compression machine Rimek mini press I (V-Tech, New Delhi, India). ${ }^{7}$

\section{Evaluation of tablets}

Thickness: The thickness of the tablet was measured with digital vernier calipers. Five measurements were taken from each batch. It was measured in $\mathrm{mm}^{8}$

Hardness: It is difficult to achieve a significant strength of ODT because of specialized excipients and process in the development of a product. The hardness of tablet is an indication of its strength. Monsanto hardness tester was used to assess the hardness of all formulation batches. It was measured in kilograms per square centimeter. ${ }^{9}$

Weight variation: The weight variation test is carried out in order to ensure uniformity in the weight of tablets.

From each of the formulation's batches, 20 tablets were randomly selected. Each of the 20 tablets was weighed separately, and the average weight with standard deviation was calculated.

Friability: Friability is the indication of loss in tablet weight by removal of fines from the surface of the tablet. Each formulation batch's accurately weighted tablets were put in a friabilator with the RPM set to 25 for $4 \mathrm{~min}$ \% Friability can be determined by standard procedure. 
Table 6: Formulation table of Montelukast sodium by direct compression method.

\begin{tabular}{|c|c|c|c|c|c|c|c|c|c|}
\hline \multirow[t]{2}{*}{ Ingredients mg/tablet } & \multicolumn{9}{|c|}{ Formulation code } \\
\hline & F1 & F2 & F3 & F4 & F5 & F6 & F7 & F8 & F9 \\
\hline Montelukast sodium & 5.2 & 5.2 & 5.2 & 5.2 & 5.2 & 5.2 & 5.2 & 5.2 & 5.2 \\
\hline Microcrytalline cellulose & 75 & 75 & 225 & 225 & 75 & 75 & 225 & 225 & 150 \\
\hline Mannitol & 212.6 & 2.9 .4 & 62.6 & 59.6 & 200.6 & 197.6 & 50.6 & 47.6 & 131.6 \\
\hline Croscarmellose sodium & 3 & 3 & 3 & 3 & 15 & 15 & 15 & 15 & 7.5 \\
\hline Magnesium stearate & 3 & 6 & 3 & 6 & 3 & 6 & 3 & 6 & 4.5 \\
\hline Aspartame & 0.3 & 0.3 & 0.3 & 0.3 & 0.3 & 0.3 & 0.3 & 0.3 & 0.3 \\
\hline Cherry flavor & 0.3 & 0.3 & 0.3 & 0.3 & 0.3 & 0.3 & 0.3 & 0.3 & 0.3 \\
\hline Red ferric oxide & 0.6 & 0.6 & 0.6 & 0.6 & 0.6 & 0.6 & 0.6 & 0.6 & 0.6 \\
\hline Tablet Weight & 300 & 300 & 300 & 300 & 300 & 300 & 300 & 300 & 300 \\
\hline
\end{tabular}

Content uniformity: For all formulation batches, content uniformity was maintained. The tablets were chosen at random, measured, and powdered. $100 \mathrm{mg}$ of powder was precisely weighed and dissolved in $100 \mathrm{ml}$ of water containing $0.5 \% \mathrm{w} / \mathrm{v}$ sodium lauryl sulphate (SLS). Whatman filter paper was used to filter the undissolved content. The dilutions were made, and the diluted solutions were compared to a blank of $0.5 \% \mathrm{w} / \mathrm{v}$ SLS in water at $344.4 \mathrm{~nm}$

Wetting time: The tablet was placed on a piece of filter paper and kept in a small petri dish $(\mathrm{ID}=6 \mathrm{~cm}$ ) consisting $10 \mathrm{ml}$ of water. The time taken by the tablet for complete wetting was recorded. ${ }^{10}$

Disintegration test: The in vitro disintegration time was measured using a USP disintegration apparatus. One tablet was placed in each of the six tubes having distilled water. The temperature was kept constant at $37 \pm 2^{\circ} \mathrm{C}$, and the time taken for complete disintegration was recorded.

Dissolution: A USP type II apparatus was used to perform in vitro drug release. The dissolution medium contained 0.5 percent w/v SLS in water and was $900 \mathrm{ml}$ in length. The RPM was set to 50, and the temperature was held at $37^{\circ} \mathrm{C} \pm 0.50^{\circ} \mathrm{C} .5 \mathrm{ml}$ of sample was pipette and replaced with 0.5 percent w/v SLS in water at intervals of 5, 10, 20, and $30 \mathrm{~min}^{11}$

Stability studies as per ICH guidelines: Among all the formulated batches, the optimized batch was chosen and subjected for stability studies for one month. The stability studies were carried out by placing the tablets in an amber colored glass vials sealed with rubber stopper in the stability chamber at room temperature $\left(25 \pm 2^{\circ} \mathrm{C}\right.$ and $\left.65 \pm 5 \% \mathrm{RH}\right)$ and at accelerated condition $\left(40 \pm 2^{\circ} \mathrm{C}\right.$ and $\left.75 \pm 5 \% \mathrm{RH}\right)$ for 1 month. Tablets were evaluated with 15 days interval for one month for drug content, hardness, disintegration time and dissolution at $30 \mathrm{~min}^{12}$

\section{RESULTS}

\section{Determination of $\lambda_{\max }$ of Montelukast sodium $6.8 \mathrm{pH}$ Buffer: Stock Solution}

Montelukast sodium (100 mg) was exactly weighed and transferred into $100 \mathrm{ml}$ volumetric flask and dissolved in $0.5 \%$ sodium lauryl sulfate (SLS), the volume was made up with the same solution to obtain a concentration of $1000 \mu \mathrm{g} / \mathrm{ml}$ (SS - I). From this SS-I, $10 \mathrm{ml}$ was pipetted in $100 \mathrm{ml}$ volumetric flask and made up the volume with $0.5 \% \mathrm{w} / \mathrm{v}$ SLS solution to get a concentration of $100 \mu \mathrm{g} / \mathrm{ml}$ (SS-II) and scanned between 200-400 $\mathrm{nm}$. The absorption maximum of $344.4 \mathrm{~nm}$ was found and used for further studies.

\section{Preparation of working standard}

Subsequent dilutions were made by taking $0.5,1.0,1.5,2.0$ and $2.5 \mathrm{ml}$ of SS-II and the volume was made up to $10 \mathrm{ml}$ with $0.5 \% \mathrm{w} / \mathrm{v}$ SLS solution



Figure 1: Standard Calibration Curve of Montelukast sodium.

resulting in final concentrations of $5,10,15,20$ and $25 \mu \mathrm{g} / \mathrm{ml}$ respectively. The absorbance of each concentration was measured at $344.4 \mathrm{~nm}$ against the reagent blank and the data was found to be linear with the $R^{2}$ value of 0.996 and a slope value of 0.003 , concentration estimates of pure Montelukast sodium showed good linearity with regression coefficient over the concentration range of $5-25 \mu \mathrm{g} / \mathrm{ml}$ passing through origin and it follows the Beer-Lambert law $(5-30 \mu \mathrm{g} / \mathrm{ml})$. The standard curve is depicted in Figure 1.

\section{Post- compression parameters}

Thickness: The thickness of the compressed tablets was measured by vernier calipers by selecting the tablets randomly from all formulations. Values for all the formulations varied from $3.37 \pm 0.03$ to $3.48 \pm 0.41 \mathrm{~mm}$. The thickness of reference product found to be $4.8 \pm 0.02 \mathrm{~mm}$. The results of thickness of the tablets for all the formulations are summarized in Table 7. The difference of thickness between the formulations and reference product is due to the convex shape of reference product.

Hardness: Hardness is the indicator of resistance of the tablets to transportation, handling and breakage under storage conditions. The compressed tablets were selected randomly from every formulation and evaluated for strength by Monsanto hardness tester and standard deviation was calculated. Hardness of all tablets was ranged from $9.5 \pm 0.04$ to $12 \pm 0.2$ $\mathrm{kg} / \mathrm{cm}^{2}$, whereas the hardness of RLD was $9.5 \mathrm{~kg} / \mathrm{cm}^{2}$ were shown in Table 7. The hardness of optimized formulation found same as that of RLD. Weight variation: To ensure proper weight of the tablets, weight variation test has been carried out. The compressed tablets of all the formulation batches passed the weight variation test as the \% weight variation was within the standard limit of $\pm 7.5 \%$. It was found to be in a range of $301 \pm 0.40$ to $305 \pm 0.47 \mathrm{mg}$, while the RLD has an average weight of $304.3 \pm 0.69 \mathrm{mg}$ shown in Table 7 . 
Table 7: Post compression parameters of formulations (F1-F9).

\begin{tabular}{cccccccc}
$\begin{array}{c}\text { Formul-ation } \\
\text { Code }\end{array}$ & $\begin{array}{c}\text { Weight variation } \\
(\mathrm{mg})\end{array}$ & $\begin{array}{c}\text { Thickness } \\
(\mathrm{mm})\end{array}$ & $\begin{array}{c}\text { Hardness } \\
\left(\mathrm{Kg} / \mathrm{cm}^{2}\right)\end{array}$ & Friability (\%) & $\begin{array}{c}\text { Wetting time (s) } \\
\text { Drug content } \\
(\%)\end{array}$ & $\begin{array}{c}\text { Disintegration } \\
\text { time }(\mathrm{s})\end{array}$ \\
\hline F1 & $305.7 \pm 0.47$ & $3.40 \pm 0.06$ & $9.7 \pm 0.10$ & $0.49 \pm 0.44$ & $17 \pm 1.02$ & $95.46 \pm 0.13$ \\
F2 & $301.9 \pm 0.4$ & $3.41 \pm 0.06$ & $9.9 \pm 0.21$ & $0.75 \pm 0.21$ & $15 \pm 0.91$ & $97.86 \pm 0.81$ \\
F3 & $301.5 \pm 0.33$ & $3.37 \pm 0.09$ & $10.8 \pm 0.02$ & $0.36 \pm 0.15$ & $36 \pm 0.98$ & $93.81 \pm 0.23$ & $63 \pm 0.95$ \\
F4 & $302.6 \pm 1.00$ & $3.37 \pm 0.05$ & $11.9 \pm 0.23$ & $0.35 \pm 0.19$ & $39 \pm 1.12$ & $96.53 \pm 0.23$ \\
F5 & $304.3 \pm 0.69$ & $3.44 \pm 0.04$ & $9.5 \pm 0.04$ & $0.39 \pm 0.31$ & $13 \pm 0.93$ & $98.40 \pm 0.48$ & $27 \pm 1.21$ \\
F6 & $303.4 \pm 0.45$ & $3.37 \pm 0.03$ & $9.5 \pm 0.16$ & $0.78 \pm 0.52$ & $16 \pm 0.89$ & $97.63 \pm 0.75$ \\
F7 & $01.8 \pm 0.27$ & $3.43 \pm 0.36$ & $12.1 \pm 0.21$ & $0.29 \pm 0.11$ & $35 \pm 1.30$ & $93.61 \pm 0.42$ & $40 \pm 0.81$ \\
F8 & $301.6 \pm 0.20$ & $3.48 \pm 0.41$ & $11.4 \pm 0.19$ & $0.49 \pm 0.14$ & $31 \pm 1.57$ & $94.16 \pm 0.32$ & $42 \pm 1.10$ \\
F9 & $301.5 \pm 0.15$ & $3.46 \pm 0.29$ & $10.2 \pm 0.31$ & $0.62 \pm 0.2$ & $21 \pm 0.89$ & $98.66 \pm 0.32$ & $49 \pm 0.75$ \\
\hline
\end{tabular}

The values represents mean $\pm \mathrm{SD}, n=3$

Friability: Poor cohesion of tablets can be identified by friability test. Friability test for all formulations was carried by roche friabilator. The results were found to be within the acceptable range (less than 1\%). The optimized batch showed $0.39 \pm 0.19 \%$ and RLD has $0.1 \%$ which are the indication of good mechanical strength.

Drug content uniformity: The developed formulations were subjected for drug content uniformity test. The tablets were selected randomly and crushed to powder. The powder equivalent to $100 \mathrm{mg}$ was accurately weighed and dissolved in $0.5 \% \mathrm{w} / \mathrm{v}$ of SLS. Serial dilutions were made and analyzed by UV spectrophotometer at $344.4 \mathrm{~nm}$. The $\%$ drug content for all the formulations were in the range of $93.6 \pm 0.42$ to $98.40 \pm 0.48 \%$. The drug content of reference product also carried out with the same procedure and it showed a drug content of $98.97 \%$. The results of drug content are shown in Table 7.

Wetting time: This test mocks the action of saliva in contact with tablet to illustrate the water uptake. The wetting time of the formulations was found to be in a range of $13 \pm 0.93$ to $36 \pm 0.98$ s and the wetting time of RLD was 12 s.

Disintegration time: It is a key step in drug absorption. In-vitro disintegration test was done for all formulations and time taken for complete disintegration of tablets was noted. Disintegration time (DT) for all formulations was found in the range of $27 \pm 1.2$ to $70 \pm 1.08 \mathrm{~s}$ and the DT of optimized formulation was close to DT of RLD i.e. $25 \mathrm{~s}$. The results of drug content are summarized in Table 7.

In vitro dissolution studies: Dissolution studies were done by USP II dissolution apparatus. The dissolution media used was $0.5 \%$ SLS. The samples were withdrawn at an interval of 5, 10, 20 and $30 \mathrm{~min}$. The absorbance of all the samples was measured by using UV spectrophotometer against blank at $344.4 \mathrm{~nm}$. Percentage drug release was calculated for each formulation by using regression equation. From the results it was evident that F5 formulation showed a maximum drug release of $97.4 \%$ at $30 \mathrm{~min}$ whereas for RLD it was found to be $98.15 \%$. The results of dissolution studies are shown in Table 7 and since the standard error is minimum it cannot be depicted in the graph shown in Figure 2.

In vitro dissolution and physicochemical characterization of the reference product (Singulair) was performed and used to define QTPP for the development of orally disintegrating tablet of Montelukast sodium, followed by identification of CQAs. Initial risk assessment was done for the excipients used in the formulation of ODTs of Montelukast sodium, to examine the effect of the formulation variables on the drug product CQAs. Although excipients rated as high and medium risk were investigated throughout the formulation development and reduced to low risk

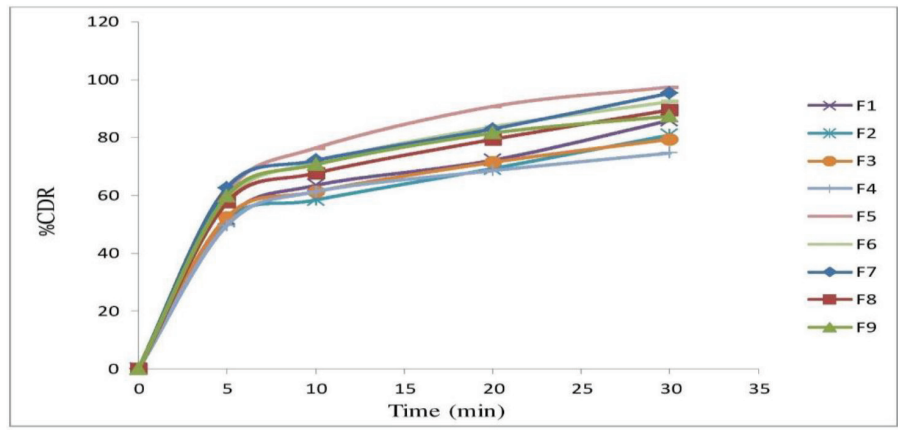

Figure 2: Cumulative Drug Release Profiles for Formulations F1-F9.

with QbD approach. Updated risk assessment of the formulation variables is shown in Table 8.

A $2^{3}$ full factorial design with one center point was applied to develop ODTs of Montelukast sodium, which provided the formulations with better dissolution and desired disintegration time. The concentration of croscarmellose sodium $\left(\mathrm{X}_{1}\right)$, microcrystalline cellulose $\left(\mathrm{X}_{2}\right)$ and magnesium stearate $\left(\mathrm{X}_{3}\right)$ were selected as independent variables. Two dependent variables (Response) were selected among them one was in vitro dissolution $\left(\mathrm{Y}^{1}\right)$ at 30 min and disintegration time $\left(\mathrm{Y}^{2}\right)$ along with post compression parameters were evaluated for given runs.

The model was found to be significant with $p<0.05$, according to ANOVA of in vitro dissolution as shown in Table 9.

The polynomial equation was generated using regression analysis and was used to draw conclusions by considering the magnitude of the coefficient as well as the mathematical sign it bears.

$$
\mathrm{Y}_{1}=82.861+13.626 \mathrm{X}_{1}-0.443 \mathrm{X}_{2}-5.093 \mathrm{X}_{3}
$$

Where $\mathrm{Y}_{1}$ is the response; in vitro dissolution, $\mathrm{X}_{1}$ had a positive coefficient value of 13.62 , indicating the positive effect of $\mathrm{X}_{1}$ on in vitro dissolution. Negative value of coefficient of $\mathrm{X}_{2}$ and $\mathrm{X}_{3}$ indicated negative effect on the response dissolution. Similarly, polynomial equation was generated by using regression analysis for response $\mathrm{Y}_{2}$ (disintegration time) was described below:

$$
\mathrm{Y}_{2}=56.955-24.766 \mathrm{X}_{1}+0.985 \mathrm{X}_{2}+3.492 \mathrm{X}_{3}
$$

The coefficient $\mathrm{X}_{1}$ had a negative value, indicating a negative result for croscarmellose sodium on the disintegration time and the both $\mathrm{X}_{2}$ and 
Table 8: Updated risk assessment of formulation variables.

\begin{tabular}{|c|c|c|c|}
\hline $\begin{array}{c}\text { Formulation } \\
\text { Variables }\end{array}$ & $\begin{array}{c}\text { Drug Product } \\
\text { CQA }\end{array}$ & Risk & Justification \\
\hline \multirow[t]{2}{*}{$\begin{array}{l}\text { Microcrystalline } \\
\text { cellulose (MCC) }\end{array}$} & $\begin{array}{l}\text { Content } \\
\text { Uniformity }\end{array}$ & Low & $\begin{array}{l}\text { The risk is reduced } \\
\text { from high to low as the } \\
\text { concentration of MCC is } \\
\text { optimized. }\end{array}$ \\
\hline & $\begin{array}{c}\text { Disintegration } \\
\text { time and } \\
\text { Dissolution }\end{array}$ & Low & $\begin{array}{l}\text { The risk is reduced } \\
\text { from medium to low. } \\
\text { As the optimized batch } \\
\text { exhibited maximum drug } \\
\text { release with hardness of } \\
9.5 \mathrm{~kg} / \mathrm{cm}^{2}\end{array}$ \\
\hline \multirow[t]{2}{*}{$\begin{array}{l}\text { Croscarmellose } \\
\text { sodium (CCS) }\end{array}$} & $\begin{array}{l}\text { Content } \\
\text { uniformity }\end{array}$ & Low & $\begin{array}{l}\text { Since low levels of CCS } \\
\text { are used, it has low } \\
\text { impact on flow property. } \\
\text { Therefore, the risk is low. }\end{array}$ \\
\hline & $\begin{array}{l}\text { Dissolution } \\
\text { and } \\
\text { Disintegration } \\
\text { time }\end{array}$ & Low & $\begin{array}{l}\text { The optimized } \\
\text { batch showed rapid } \\
\text { disintegration and } \\
\text { dissolution. Hence, the } \\
\text { risk is reduced to low }\end{array}$ \\
\hline \multirow[t]{3}{*}{$\begin{array}{l}\text { Magnesium } \\
\text { stearate }\end{array}$} & $\begin{array}{l}\text { Content } \\
\text { uniformity }\end{array}$ & Low & $\begin{array}{c}\text { Low levels are used } \\
\text { so the low impact on } \\
\text { content uniformity. The } \\
\text { risk is low }\end{array}$ \\
\hline & $\begin{array}{c}\text { Disintegration } \\
\text { time }\end{array}$ & Low & $\begin{array}{c}\text { It enhances } \\
\text { disintegration time. } \\
\text { therefore, the risk is low }\end{array}$ \\
\hline & Dissolution & Low & $\begin{array}{l}\text { The risk is reduces to low. } \\
\text { Minimum concentration } \\
\text { produced desired results }\end{array}$ \\
\hline
\end{tabular}

Table 9: Analysis of variance: in vitro dissolution (\%CDR) and disintegration time(s).

\begin{tabular}{cccccc}
\hline \multicolumn{5}{c}{ Analysis of Variance in vitro dissolution (\%CDR) } \\
\hline Source & SS & $\mathrm{d}_{\mathrm{f}}$ & $\begin{array}{c}\text { Mean } \\
\text { square }\end{array}$ & F-ratio & p-value \\
\hline Regression & 423.681 & 3 & 141.227 & 18.258 & $\mathbf{0 . 0 0 4}$ \\
Residual & 38.675 & 5 & 7.735 & & \\
\hline \multicolumn{5}{c}{ Analysis of Variance: Disintegration time (s) } \\
\hline Regression & 1259.521 & 3 & 419.84 & 18.258 & $\mathbf{0 . 0 0 4}$ \\
Residual & 337.368 & 5 & 67.474 & \\
\hline \multicolumn{7}{c}{}
\end{tabular}

$\mathrm{X}_{3}$ were indicated positive effect on the response. $p$ value for disintegration time found to be $0.038(p<0.05)$ Table 9 which indicated model was significant.

The optimized batch was compared with the reference product for in vitro drug release shown in the Figure 3 and also compared with other important parameters which were tabulated in Table 10. Figure 4 represents the response surface plots showing the effect of concentration of microcrystalline cellulose, croscarmellose sodium and magnesium stearate. With increase in the concentration of CCS, the \% drug dissolution at $30 \mathrm{~min}$ was increased, whereas increase in concentration of MCC and magnesium stearate resulted in a nominal decrease in \% drug release.

Almost all the high and medium risks associated with formulation variables were reduced to low risk and control strategy was defined



Figure 3: Cumulative Drug Release Profile of F5 and RLD product (Singulair).

Table 10: Comparison of optimized formulation with the reference product.

\begin{tabular}{ccc}
\hline Evaluation parameters & $\begin{array}{c}\text { Optimized } \\
\text { formulation (F5) }\end{array}$ & $\begin{array}{c}\text { Reference product } \\
\text { (Singulair) }\end{array}$ \\
\hline Drug Content (\%) & 98.27 & $98.97 \pm 2.003$ \\
Disintegration time (s) & $27 \pm 1.05$ & $25 \pm 0.08$ \\
Weight variation (mg) & $304.3 \pm 0.69$ & $301.2 \pm 0.21$ \\
$\begin{array}{c}\text { Dissolution at 30 min } \\
\text { (\%CDR) }\end{array}$ & 97.45 & $98.15 \pm 3.85$ \\
\hline
\end{tabular}

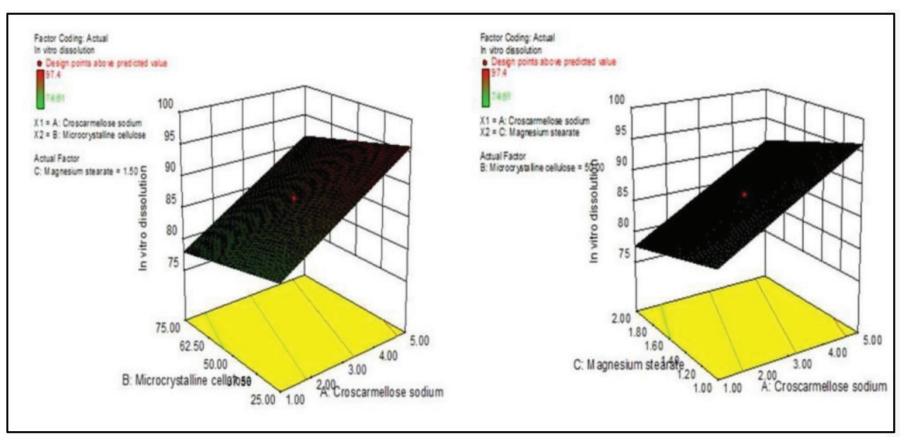

Figure 4: 3D Response Surface Plot of in vitro Dissolution vs Factor 1, Factor 2 and in vitro Dissolution vs Factor 1 and Factor 3.

giving better control over drug product development. Comparison with the optimized formulation (F5) and reference product (Singulair) indicated that the QbD based approach in development of formulation was effectively utilized with the same quality product attributes.

The effect of microcrystalline cellulose and croscarmellose sodium on disintegration time is depicted in Figure 5, which indicates that increase in the concentration of CCS decreased the disintegration time and no significant effect was observed with increase in concentration of MCC and magnesium stearate. An overlay plot was developed defining the design space with QTPPs, dissolution at 30 min with drug release not less than $80 \%$ and disintegration time with less than 60 s. The design space was represented in Figure 6. The green zone in the design space represents a zone in which any experimentation shall lead to achieve desired drug product CQAs and the grey zone indicates failure to meet the drug product CQAs. The overlay plot dictates 1-5\% of CCS and MCC in the range of $25-60 \%$ at $1 \%$ Magnesium stearate concentration are the proven ranges in order to arrive at the defined QTPPs. Hence, as a control strategy, 5\% CCS, 25\% MCC and 1\% magnesium stearate was proposed as optimized formulation as shown in Table 11. 


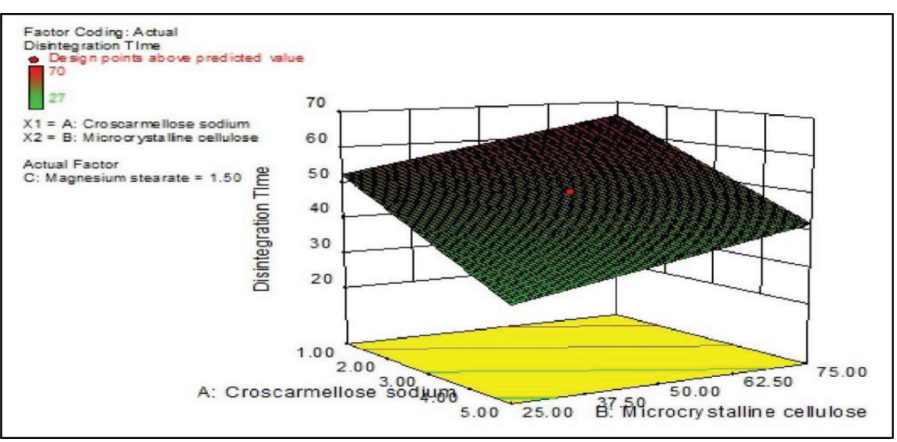

Figure 5: 3D Response Surface Plot of Disintegration time vs Factor 1 and Factor 2.

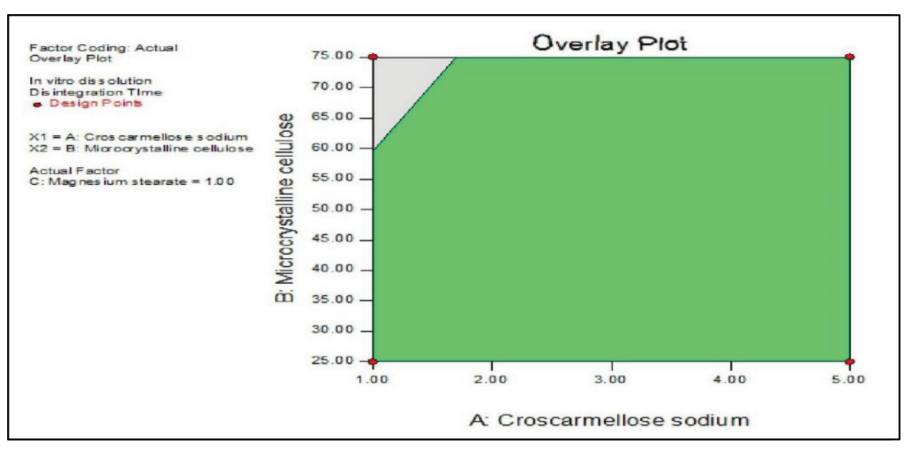

Figure 6: Overlay Plot.

Table 11: Control strategy for ODTs of Montelukast sodium.

\begin{tabular}{|c|c|c|c|c|}
\hline Factor & $\begin{array}{l}\text { Range } \\
\text { studied }\end{array}$ & $\begin{array}{c}\text { Proven } \\
\text { acceptable }\end{array}$ & $\begin{array}{l}\text { Control } \\
\text { strategy }\end{array}$ & $\begin{array}{c}\text { Purpose of } \\
\text { control }\end{array}$ \\
\hline $\begin{array}{l}\text { Microcrystalline } \\
\text { cellulose (MCC) }\end{array}$ & $25-75 \%$ & $25 \%-60 \%$ & $25 \%$ & $\begin{array}{c}\text { Levels of MCC } \\
\text { affect flowability } \\
\text { and hardness, } \\
\text { dissolution, } \\
\text { disintegration } \\
\text { time, Content } \\
\text { uniformity. }\end{array}$ \\
\hline $\begin{array}{l}\text { Croscarmellose } \\
\text { sodium(CCS) }\end{array}$ & $1-5 \%$ & $1-5 \%$ & $5 \%$ & $\begin{array}{c}\text { Concentration } \\
\text { of affects both } \\
\text { dissolution and } \\
\text { disintegration } \\
\text { time }\end{array}$ \\
\hline $\begin{array}{l}\text { Magnesium } \\
\text { stearate }\end{array}$ & $1-2 \%$ & $1 \%$ & $1 \%$ & $\begin{array}{c}\text { Higher } \\
\text { concentration } \\
\text { of magnesium } \\
\text { stearate retards } \\
\text { dissolution. }\end{array}$ \\
\hline
\end{tabular}

The optimized batch was selected and stability studies were performed. Various evaluation parameters have been done and there were no significant changes and showed an excellent stability and the results of stability studies is presented in Table 12.

\section{DISCUSSION}

Implementing QbD helped to acquire better understanding of overall development of stable formulation. Application of DOE using $2^{3}$ full factorial design with one center point aided in better formulation and
Table 12: Stability studies of optimized formulation.

\begin{tabular}{|c|c|c|c|c|c|}
\hline \multirow{3}{*}{ Parameters } & \multicolumn{5}{|c|}{ Optimized Formulation } \\
\hline & \multirow[t]{2}{*}{ Initial } & \multicolumn{2}{|c|}{$\begin{array}{c}\text { Room Temperature } \\
25^{\circ} \mathrm{C} \pm 2^{\circ} \mathrm{C} / \mathrm{RH} 60 \pm \\
5 \%\end{array}$} & \multicolumn{2}{|c|}{$\begin{array}{c}\text { Accelerated } \\
\text { Temperature } 40^{\circ} \mathrm{C} \pm \\
2^{\circ} \mathrm{C} / \mathrm{RH} 75 \pm 5 \%\end{array}$} \\
\hline & & 15 Days & 30 Days & 15 Days & 30 Days \\
\hline $\begin{array}{l}\text { Hardness } \\
\left(\mathrm{kg} / \mathrm{cm}^{2}\right)\end{array}$ & $9.5 \pm 0.23$ & $9.4 \pm 1.52$ & $9.5 \pm 0.57$ & $9.5 \pm 0.83$ & $9.6 \pm 0.15$ \\
\hline $\begin{array}{l}\text { \% Drug } \\
\text { Content }\end{array}$ & $97.03 \%$ & $96.34 \%$ & $96.49 \%$ & $97.15 \%$ & $97.8 \%$ \\
\hline $\begin{array}{c}\text { Disintegration } \\
\text { Time (s) }\end{array}$ & $27 \mathrm{~s}$ & $28 \mathrm{~s}$ & $28 \mathrm{~s}$ & $29 \mathrm{~s}$ & $29 \mathrm{~s}$ \\
\hline $\begin{array}{l}\text { Dissolution at } \\
30 \text { min \%CDR }\end{array}$ & $96.79 \%$ & $96.34 \%$ & $96.49 \%$ & $97.1 \%$ & $97.20 \%$ \\
\hline
\end{tabular}

optimization of ODT of Montelukast sodium with a good drug release, drug content uniformity and disintegration time. Montelukast sodium revealed linearity in the range of $5-25 \mu \mathrm{g} / \mathrm{ml}$ at $\lambda_{\text {max }}$ of $344.4 \mathrm{~nm}$ in $0.5 \%$ w/v SLS solution.

Equation was developed for the calculation of concentration:

Absorbance $(y)=0.025 x+0.003$, Regression co-efficient $\left(R^{2}\right)=0.9963$

Hence, it can be concluded from the study that the above methods are precise, accurate and reproducible. The calibration curve was found to be linear with correlation coefficient of $\left(R^{2}>0.996\right)$ over the concentration range from $5-25 \mu \mathrm{g} / \mathrm{ml} .{ }^{13}$ All the formulations were developed and evaluated for thickness, hardness, friability, wetting time, weight variation, drug content, disintegration time, in vitro dissolution. The thickness of the tablets was found to be relatively consistent in all the formulation batches. Hardness of the tablets for all the formulations indicated the good mechanical strength. Data obtained from the friability test of all the formulations were within the acceptable range, indicating the capability of the tablets to withstand the mechanical shocks and frictions during handling. The percent deviation of all the formulations were found to be within the range of $\pm 7.5 \%$ of the weight. Thus, all the formulations complied with weight variation tests as per standard specifications. Wetting time of all the formulations were found to be satisfactory. The percentage drug content of tablets of all batches was found to be within the acceptable limits indicating uniform distribution of the drug in the formulated tablets as per the specifications. The in vitro disintegration time depicted the action of croscarmellose sodium, which is a better disintegrant. From the results of in vitro dissolution studies, it can be concluded that F5 formulation showed maximum drug release within 30 min. Among all the formulation batches, (F1 - F9) F5 was picked as optimized formulation due to its minimum disintegration time also the maximum drug release at $30 \mathrm{~min}$. The ANOVA results showed that the model was significant for both the responses i.e. in vitro dissolution and disintegration time. The $3 \mathrm{D}$ response surface plots indicated that increase in levels of superdisintegrant (croscarmellose sodium), increases in vitro drug release and increase in the concentration of lubricant (magnesium stearate) decreases drug release.

Croscarmellose sodium promoted disintegration time at high concentrations. Increase in the concentration of diluent (microcrystalline cellulose) decreases the disintegration time due to increased hardness of the tablets and the magnesium stearate has no impact on disintegration time. The optimized batch was selected and subjected to accelerated stability testing. The stability data was evident that there were no notable changes with the values of hardness, drug content, disintegration time 
and in vitro dissolution of optimized formulation and thus, optimized formulation showed an excellent stability. The high and medium risks associated with excipients and components of drug substances were reduced to low risks. A control strategy was defined depicting a better control over the entire drug product development. Hence it was concluded that the stable orally disintegrating tablets containing Montelukast sodium were developed by planning and implementing quality by design approach $(\mathrm{QbD})$ which helped in better understanding and control over the entire drug product development.

\section{CONCLUSION}

In the present study, application of QbD approach for the development of Montelukast sodium orally disintegrating tablets involved many stages. One of the major stages was to perform initial risk assessment for the purpose of linking the impact of CMAs to drug product CQAs. The formulation variables classified as high and medium risk on the drug product CQAs were reduced to low risk. Microcrystalline cellulose (MCC) showed high risk to content uniformity (CU) and medium risk to disintegration and dissolution. Croscarmellose sodium (CCS) exhibited high risk to disintegration and dissolution and magnesium stearate showed high risk only to dissolution as its concentration used was low. By using DOE v 13.2 optimization has been carried out and the risks were mitigated to low risk. Amongst the formulations, F5 was considered as optimized, because of its maximum drug release with minimum disintegration time. Montelukast orally disintegrating tablets were developed and optimized with the help of a systematic QbD analysis.

\section{CONFLICT OF INTEREST}

The authors declare no conflict of interest.

\section{ACKNOWLEDGEMENT}

The authors are very much thankful to Apotex Research Private Ltd., (Bengaluru, India) for providing Montelukast sodium as a gift sample and Elegant Pharma (Hubballi, India) for providing excipients as gift samples. Authors also express gratitude to KLE College of Pharmacy, Hubballi for providing infrastructure and timely help.

\section{REFERENCES}

1. Pallothu SC, Sandeepthi N. Formulation and evaluation of fexofenadine oral disintegration tablets for improvising patient compliance. Int J Pharm Anal Res. 2018;7(1):16-28.

2. Joshi R, Garud N, Akram W. Fast dissolving tablets: a review. Int J Pharm Sci Res. 2020:1562-70.

3. Abolfazi A, Maryam B. Design, formulation and physicochemical evaluation of montelukast orally disintegrating tablet. Int J Prev Med. 2016;120(7):1-8.

4. Güncan G, Yegen G, Mesut B, Aksu B, Özsoy Y. Formulation design of the oral disintegrating tablets including alfuzosin hydrochloride with risk evaluation via quality by design. actapharm. 2017;55(2):57-76. doi: 10.23893/1307-2080. APS.05512.

5. Patel TB, Patel TR, Suhagia BN. Formulation development of donepezil hydrochloride oral disintegrating tablets using quality by design approach. Int J Pharm Sci Res. 2016;7(5):2097-108.

6. Adepu AR, Bhogale V. Process development, evaluation and controlling of parameters during formulation development of granisetron $\mathrm{HCl}$ as an ODT by QbD concept. Int J Pharm Res Sch. 2016;5(2):189-201.

7. Mahesh E, Kiran Kumar GB, Ahmed MG, Kumar KP. Formulation and evaluation of montelukast sodium fast dissolving tablets. Asian J Biomed Pharma Sci. 2012;2(4):75-82.

8. Usmani M, Shoaib M, Nasiri M, Yousuf R, Zaheer K, Ahmed K. Development and evaluation of orally disintegrating tablets of montelukast sodium by direct compression method. Trop J Pharm Res. 2015;14(1):1-6. doi: 10.4314/ tjpr.v14i1.1.

9. Chowdary KPR, Shankar KR, Suchitra B. Recent research on orodispersible tablets: a review. Int J Pharm Res Appl Sci. 2014;4(1):64-73.

10. Gnanaprakash P, Monila P, Gobinath M, Sravani T. Formulation and Evaluation of Orodispersible Tablets of theophylline. Int J Pharm Health Care Res. 2013;1(4):161-8.

11. Rewar S, Singh CJ, Bansal BK, Pareek R, Sharma AK. Oral dispersible tablets, an overview, development, technologies and evaluation. Int J Res Dev Pharm Life Sci. 2014;3(6):1223-35.

12. Pawar H, Varkhade $C$, Jadhav P, Mehra K. Development and evaluation of orodispersible tablets using a natural polysaccharide isolated from Cassia tora seeds. Integr Med Res. 2014;3(2):91-8. doi: 10.1016/j.imr.2014.03.002.

13. Patel NK, Chouhan P, Paswan S, Soni PK. Development and validation of a UV spectrophotometric method for simultaneous estimation of combination of montelukast sodium in presence of levocetirizine dihydrochloride. Pharm Lett. 2014;6(3):313-21.

Article History: Submission Date : 05-07-2021; Revised Date : 14-08-2021; Acceptance Date : 04-09-2021.

Cite this article: Sholapur HPN, Dasankoppa FS, Channabasavaraja M, Sagare RD, Abbas Z, Nanjundaswamy NG, Sai LS, Kshatriya K. Quality by Design Approach for Design, Development and Optimization of Orally Disintegrating Tablets of Montelukast Sodium. Int. J. Pharm. Investigation. 2021;11(3):288-95. 